\title{
RUPTOR OVI, THE NUMBER OF MOULTS IN DEVELOPMENT, AND METHOD OF EXIT FROM MASONED NESTS. BIOLOGY OF EUMENINE WASPS, VII.
}

\author{
By Kenneth W. Cooper, \\ Hanover, N. H.
}

Many common mason wasps of the eumenine genera Ancistrocerus, Symmorphus, and Rygchium construct nests which, for a period from a month and a half to nearly ten months, must enclose and protect the food supply and the young wasps during their helpless egg, larval and pupal stages. These nests may be made by cross-partitioning into a succession of cells ready-formed, empty, blind tunneis, such as abandoned burrows of wood-boring insects, hollow stems of plants, or even holes left by large nails. Nearly each cell, as it is made, receives an egg and sufficient paralysed prey (caterpillars or phytophagous beetle larvae, depending on the species of wasp) for development of a newly hatched larva to the adult wasp. The protective plug that closes the completed nest, and the partitions between cells, are made by the female wasp from a cohesive mortar of clay, loam or sand, worked up with water (and perhaps "saliva"). Other wasps of these genera, and of more or less related genera such as Eumenes and Pseudomasaris (a masarine), fashion their entire nests of mortar, building aggregates of masonry tubes, pots, or lumpy masses of cells affixed to plant stems, bark, or the exposed faces of rocks. Not only must the nests of mason wasps be hard and sufficiently strong to resist possible mechanical stresses and penetration by parasites but, being often subject to rain and melting snow, like man's masonry, they must withstand dissolution when built in exposed situtions.

It is not surprising that the walls and plugs of such nests serve other functions than mere protection. For example, they prevent cannibalism among the brood, they serve hygienic functions, they make possible the use of lightly paralysed prey, and so on. They also serve as the channel of an essential communication system between mother and young that their very presence necessitates; these and other matters I have discussed elsewhere (Cooper 1957). But if the cement- or plaster-like masonry succeeds in keeping other insects out of the nest, as in general it does so well, by what means do the developed wasps, imprisoned within the nest, gain their exit?

Manuscript received by the editor December 5, 1966 
There is an earlier point too in the life of each wasp at which, if it is to survive, it must likewise break out of an enclosure the walls of which it did not make. This first passage is of course prelude to the onset of active larval life, being penetration of the tough chorion or "egg shell". It is my aim to show how each of these escapes is accomplished. So far as I can discover, only Nielsen (1932) has disclosed the special aspect of exit from a masoned nest, and this in a species of Symmorphus. The means of escape from the chorion seems a wholly new observation, even though the mechanism may prove to be widespread among Hymenoptera. In addition I shall show that these wasps have a fixed number of larval moults, an aspect of the biology of hunting wasps about which there has been considerably uncertainty. The records which now follow have all been :nade from broods originally established by mother wasps in "trap nests". 1. Hatching of Ancistrocerus antilope (Panz).

When a newly completed, provisioned cell of Ancistrocerus antilope is opened, just as with most other eumenids, the cream colored, slightly bowed, elongate and turgid egg is normally found above or among the paralysed prey. In either case, the blunt caudal end of the egg is firmly attached to the ceiling of the cell by a short, flexible suspensory thread that is from 0.5 to $0.8 \mathrm{~mm}$ long and $14-16 \mu$ in diameter (fig. I). The egg itself is about $2.7-2.8 \mathrm{~mm}$ long by 0.8 to $0.9 \mathrm{~mm}$ wide, rather small for a eumenid's egg to judge from the sample of eggs of 13 species measured by Iwata (1955). When fresh, the chorion is tough, seemingly inelastic, and leathery to manipulation by forceps, even though very thin. At $20^{\circ} \mathrm{C}$, the egg hatches some 2 to 4 days after it is laid (Cooper 1953).

Shortly before hatching occurs, the brownish tips of the mandibles and the segmentation of the body of the larva can just be seen through the chorion. The first larval movements that I detected were of the forebody, and mandibles. Thereafter they may include intermittent gentle squirmings of the entire body. The larva evidently takes up most of the fluid lying between it and the envelope of the egg during its first exertions, for the still intact chorion now everywhere becomes closely appressed to the larva, and may then follow the contours of the larva's body segments as Taylor (1922) has observed. Three denticles, at the levels of the 4 th, 5 th and 6 th postcephalic segments of the larva, thereupon burst the chorion on each side of the egg, minute amounts of fluid escaping when this happens. The caudal third of the chorion collapses and shrivels, forming two or more folds that radiate lengthwise from near the base of the suspensory filament, reducing the free space at the caudal pole of the egg (fig. 2). 


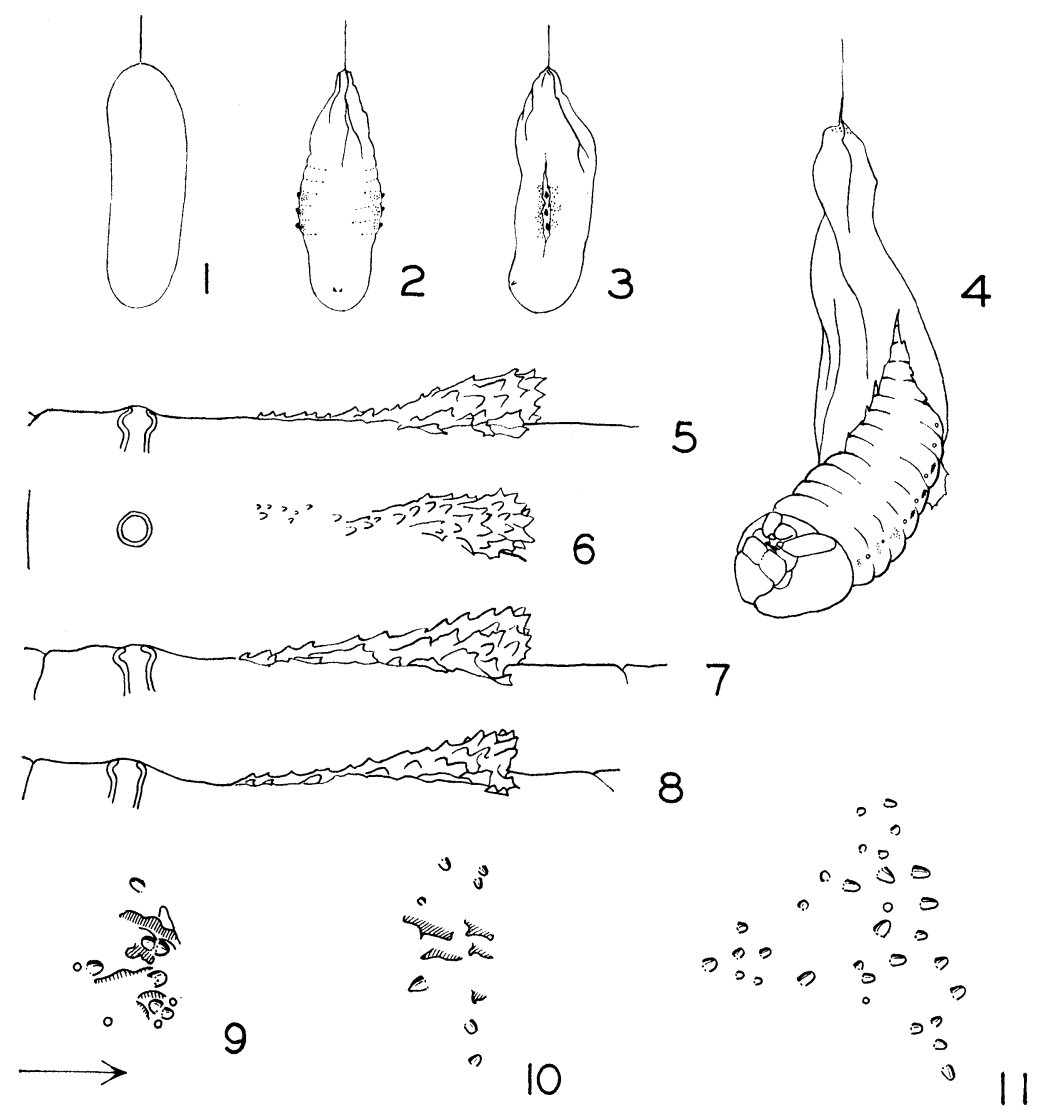


With denticles protruded through the chorion, the larva spasmodically shortens and thickens its body (for periods of three to five seconds), as though forcing itself, by creeping movements, against the lateral walls of chorion and the cephalic pole of the egg. These exertions drive the denticles, as though saw-teeth, lengthwise through the lateral chorion of the medial third of the egg, ever widening the two more or less ragged rifts both fore and aft (fig. 3). Following each period of rest, lateral pressure, renewed each time that the larval forebody thickens, tears the rent chorion more widely until, finally, the whole anterior half of the egg lies open, cut into dorsal and ventral flaps in a fashion that reminds of Wheeler's (I889) description of hatching of the beetle Leptinotarsa decemlineata (Say). With its anterior half free of the egg but its hinder body still enclosed and adherent within the shriveled chorion, the newly emerged larva immediately commences to feed on the nearest prey (fig. 4). Though hatched, the larva does not normally quit the chorion until it casts its first moult.

In all, I have watched I 6 eggs hatch. The speediest case took 20 minutes, the longest something less than 90 minutes but more than an hour. On the average, with the temperature ranging between $20^{\circ}-28^{\circ} \mathrm{C}$, hatching requires 45 minutes, with a standard deviation of \pm 9 minutes. The chorions of most eggs were bilaterally split as I have described, but in 3 cases the larva's denticles penetrated one side of the egg only. In each of these instances, the single rent was ultimately enlarged by the movements of the larva until the whole of its forebody emerged; these larvae seemed in no way handicapped by failure of the egg to be split on both sides.

Figures 1-3. - Hatching of the egg of Ancistrocerus antilope (Panz.), magnif. $9 X$; fig. 1.-unhatched egg; fig. 2.-egg viewed from ventral surface, ruptor ovi of abdomen have perforated chorion on each side, chorion collapsed caudally, mandibular tips of larva visible at cephalic pole (below); fig.3-egg at mid-hatching seen from the right side, note tear in chorion, ruptor ovi of abdomen, and tips of manbibles at lower left.

Figure 4-Newly hatched larva in feeding position, magnif. $15 \times$; : he larva will normally adhere to the split chorion until instar-2.

Figures 5-8-Abdominal ruptor ovi, magnif. 390X; in each case the spiracle to the right (anterior) originates from the segmental tracheal trunk of the preceding body segment. Fig. 5.-ruptor of abdominal segment-1, nearly profile view. Fig. 6.-ruptor of abdominal segment-1, above. Fig. 7.-ruptor of abdominal segment-2, in "profile". Fig. 8.-ruptor of abdominal segment-3, in "profile".

Figures 9-11 - Spinous sets and laminae (hatched) of the ruptor ovi of thoracic segments-1, -2 , and -3 respectively, magnif. $500 X$, see text.

Note:- Orientation of ruptor ovi in figs. 5-11 is indicated by arrow below fig. 9, pointing caudally; all figures are freehand sketches, to scale. 
2. The ruptor ovi, or egg bursters

The newly hatched larva of Ancistrocerus antilope has defined sets of minute, fixed spines (0.8-9 9 long $\times 0.8-6 \mu$ in diameter) on the dorso-lateral surfaces of the three thoracic segments and the first three abdominal segments (figs. 4-II). In each case these sets of spines are located anterior and very slightly dorsal to each corresponding spiracle, at or near the mid-length of its segment; the spines are not moveable, and their bases appear to be continuous with the cuticle. Unlike the general scatter of spines in the thoracic sets, nearly every spine of each field on the first three abdominal segments is at least partially coalesced with its neighbors. The massive, caudally directed, hypertrophied, pale amber teeth thus formed on the sides of the anterior abdomen bear many smaller denticles and blade-like serrations that also point caudally (figs. 5-8). From the base of their most cephalad component spine to their caudal tip, these elongated, composite abdominal teeth are, on the average, some 6o-8o $\mu$ long $\times 20-30 \mu$ at their widest. Each rises at an average angle of $12^{\circ}-15^{\circ}\left(30^{\circ}\right.$ in an extreme instance) from its anterior origin on the lateral surface of the larva to a caudad peak that is some I4-I $8 \mu$ high.

The dentate fields of the three thoracic segments are more loosely organized, their spines and blade-like projections not coalescing into a single large structure. That on each side of thoracic segment-I consists of IO-I 4 irregularly directed, stubby spines, and 4 or more blade-like ridges or denticles arrayed in a patch that is much wider (ca $30 \mu$ ) than long (ca $22 \mu$ ) (fig. 9). The spinous sets on each side of thoracic segment-2 are also wider (ca $30 \mu$ ) than long (ca $18 \mu$ ), each possessing 7-IO small spines and four or more lamina-like denticles (fig. IO). As in the case of the sets on segment-I, those on segment-2 have their spines and denticles projecting in different directions, more or less haphazardly, and several spines and blades may appear coalesced.

Each field of spines on thoracic segment-3 is much larger than those of segments-I and-2, differing also by being roughly triangular in shape, with the apex of the triangle pointing forward (fig. I I). The wide base of this field lies caudad, roughly normal to the long axis of the larva, and approximately equal in length to the altitude (ca 60 and $55 \mu$ respectively). Individual spines are for the most part well spaced, numerous (ca 25-35), and directed caudally. In some larvae, however, 3 or more of the posterior denticles may be laminate and clustered, much as those of the first two thoracic fields. 
At hatching, when the larva has taken up the fluid enclosed by the intact chorion and commences to creep, it is quite likely that the spines and laminate denticles of the thoracic fields of each side assist chiefly in the pushing and creeping movements of the larva by gaining purchase against the chorion; in doing so, they probably no more than abrade the inner face of the chorion, for they do not appear to penetrate it. It is quite otherwise, however, with the compact, high multidentate teeth of the first three abdominal segments.

Drawn forward against the appressed chorion, ratchet like, the strongly projecting teeth of the first three abdominal segments must receive litle resistance. But when moved rearwards as the larva squirms forward, their spines and blades thrust into the chorion, perforating, tearing and sawing it in the manner I have described. Once the chorion is slit open along each side of the middle third of the egg, those spines of the thoracic fields which are directed forward or laterally very likely engage the anterior end of each lateral rift as the larva alternately elongates and contracts, thereby extending the tear in the chorion still further forward.

There can be little question that all of these fields of spines are adaptations solely related to hatching, for they are present on the cuticle of the first instar larva only, and are shed with that cuticle at the first moult. Indeed the integument of the second instar has no vestige or reminder of either the specialized fields of spines of the thorax or of the composite teeth of the first three abdominal regments that so effectively rip the egg open at the onset of independent larval life. These structures are therefore ruptor ovi (or "egg bursters") in the strictest sense, and their presence marks the larval development of $A$. antilope as hypermetamorphic.

3. The number of instars

For more than a century there has been uncertainty and dispute as to whether hunting wasps normally have a fixed number of moults, hence of instars, in their development. So far as eumenine wasps are concerned, the uncertainty is very likely due to the fact that, sooner or later, most cast larval exuvia are nearly always eaten by the wasp larva as it feeds. The exuvium peels back to the tacky or viscid caudal end of the larval wasp at ecdysis, with the exoskeleton of the head capsule, split along its median suture, projecting from the ventral surface of the last abdominal segments of the larva. The exuvium is then generally held there as the larva, by arching its body and pushing with its abdomen, presses the prey against its mouth. As the last remnants of a caterpillar are eaten, so also are any moults 
that still cling to the larva's abdomen. For this and other reasons the only exuvium ordinarily found in the pupal cell of a wasp is that of the terminal larval moult. Accordingly there are three conditions that must be satisfied for a direct demonstration of the number of instars: ( I ) the first instar larva must be identified with certainty, generally by witnessing hatching, (2) exuvia must be removed when shed, or very shortly thereafter, and (3) closely and appropriately spaced observations must be continued from hatching to the emergence of the imago.

These conditions have been met for 16 individuals of $A$. antilope reared in isolation chambers on the original prey with which each was provided by its mother. In every case the full number of moults was six. The first four moults mark the limits of the first four larval stages, which are devoted solely to feeding and growth. The fifth stage larva, unlike the earlier four, does not moult to a feeding individual. It completes feeding, cleans and "varnishes" its cell, generally disposing of any exuvia that may remain, spins a cocoon (which may be incomplete in $A$. antilope), passes its meconium, and becomes a quiescent prepupa (or "mature larva"). If of the spring brood, the fifth larval moult generally occurs about 3.5 to 4.5 days after the meconium has been voided, releasing the pupa which is the sixth instar. The fifth instar larva of the summer brood diapauses after passing the meconium, and only in the following spring does the fifth moult occur. The final, or sixth moult, occurs after the pupa has become fully colored, and it is that final moult which frees the imago within its cocoon. The approximate times at which each of the first five moults occurs after hatching, and the average durations of each instar (at a temperature from $20^{\circ} \mathrm{C}$ to $28^{\circ} \mathrm{C}$ ) are given in table $\mathrm{I}$; the fifth moult is there recorded for first (spring) brood individuals only, for that of members of the summer brood occurs in the following spring some 8 months or so after the onset of diapause. It should be noted that the egg stage is considered to have ended when the developed larva commences to cut its way out of

Table I (see text for explanation)

$\begin{array}{rclc}\text { Occurrence of: } & \text { on day } & \text { duration of: } & \text { days } \\ \text { hatching } & \mathrm{O} & \text { egg stage } & 2.5 \\ \text { ecdysis-I } & 3.2 & \text { instar-1 } & 0.7 \\ \text { ecdysis-2 } & 4.0 & \text { instar-2 } & 0.8 \\ \text { ecdysis-3 } & 5.0 & \text { instar-3 } & \text { I.O } \\ \text { ecdysis-4 } & 6.3 & \text { instar-4 } & \mathrm{I} .3 \\ \text { ecdysis-5 } & \mathrm{I} 7 & \text { instar-5 } & \text { I0.7 } \\ \text { ecdysis-6 } & 29-36 & \text { pupa } & \mathrm{I} 2-\mathrm{I} 9\end{array}$


the egg, and the duration of instar-I entered in the table includes the time (about 45 minutes) involved in hatching. The average duration of instar-I after rupture of the chorion is 16 hours.

4. Exit from the nest

All who have reared large numbers of mason wasps in the laboratory from intact nests are familiar with the sharp, rasping scratches which foretell emergence of the imagos, as well as with the dessicated, powdery debris of the cut walls and terminal plug that remains long after the wasps have cleared the nest. But all are equally familiar with nests from which few or no wasps finally emerge, despite earlier, prolonged audible indications that emergence had been attempted. When such nests constructed in burrows are cut open, dead wasps may be found jammed in single file at the terminal plug, with the remains of dismembered and chewed sibs pushed to the rear. I suspect that such observations have led to the quite general belief that mason wasps simply cut their way out with their mandibles, as well as to the general wonder that they can do so from nests so hard, cement-like and thick as those, say, of masarid wasps (e.g., see Davidson 1913, Ferton 1921, Hicks 1927, 1929). That they sometimes fail to do so seems to be taken as only natural.

It is true that the eumenid and masarid wasps (at least $P_{\text {sendo- }}$ masaris vespoides [Cress.]) do cut their way out with their mandibles, but the task is lightened in at least two ways. For one, it is easier to pass through a plug or wall from the inside than from the outside. This is because the inner faces of plugs and crosswalls are necessarily irregular and less compact in texture, as well as somewhat convex, for the masoning wasp is unable to control the irregularities and to press them down tightly with her head. For this reason portions of the inner faces of walls and plugs more readily break off when pried or rasped. For another, these wasps treat refractory regions just as their mothers did when first compounding the mortar; the eclosing adults soften the walls by moistening them to mud, as Nielsen (1932) first discovered in the case of emerging Symmorphus sinuatus (Fab.). Reg.ons of walls softened in this way may then be cut with ease.

This certainly is the case for emerging Ancistrocerus antilope (Panz.), A. catskill (Sauss.), A tigris (Sauss.), Symmorphus cristatus (Sauss.), Parancistrocerus fulvipes (Sauss.), Monobia quadridens (Linn.), Rygchium foraminatum (Sauss.), and R. megaera (Lepel.) among the eumenines, as well as for Pseudomasaris vespoides (Cress.), all of which I have studied. When wasps fail to cut their way out of a nest, it is often the case that one or more plugs are so thick and unworkable (a terminal plug may be as much as $20 \mathrm{~mm}$ 
thick) that the wasps run out of both fluid and energy, or that the wasps themselves are relatively dehydrated to start with, as may happen when nests have been kept in heated rooms.

A wasp ready to emerge, but still resting in its cocoon, will emit a drop of fluid from its mouth if disturbed by the observer, and the numbers of nests failing to give emergence can be greatly increased if each wasp, before it is ready to leave its cell, is "milked" of its fluid reserve. Those that do emerge after such treatment are generally from nests with relatively thin or friable walls, or presumably the wasps from them are those of which at least one regained sufficient fluid by butchering siblings. If a wall can be readily cut, even though not moistenable by water, wasps will chew through it if the thickness is not too great. Thus $A$. antilope will cut its way out of nests in which all partitions and the terminal plugs have been replaced with hard beeswax walls from 2 to $4 \mathrm{~mm}$ or more in thickness.

In Ancistrocerus antilope the source of the fluid is the proventriculus which, in a newly eclosed imago, will deliver from $5 \mathrm{~mm}^{3}$ to more than $12 \mathrm{~mm}^{3}$ of clear liquid. Very likely it is the proventriculus which supplies the fluid in all of the other cases, although that has not been determined.

Davidson (1913) suggests that the cup-like caps of the very hard, upright cells of the nest of Pseudomasaris vespoides collect rain which softens them, permitting each wasp to cut its way out. Hungerford (1.937) of course threw doubt on this view when he showed that $P$. occidentalis (Cress.), the nest of which is also very refractory but not provided with cupped closures, emerges without a prior external softening of the region of exit. Actually $P$. vespoides itself softens the walls at the base of the cap of its cell from within, applying liquid from its mouth. It then chews away the now muddy, sandy coverings, turning from time to time, so that it nearly symmetrically enlarges a hole through the cap. It then trims the hole with its mandibles until it can wriggle its way out - which it does as though walking on the apices of its femora. In the instance observed, the male wasp at one point put its forelegs out through the hole, yet it did not try to pull itself out with them. Early during the cutting of the emergence hole, as the wasp turned in its cell, the left antenna was pushed between the mandibles. It remained there during the entire time (about 20 minutes) that the hole was being enlarged, in no way seeming to cause difficulty.

Discussion

The study of hatching and moulting, no less of many other aspects of the developmental biology of burrow-nesting eumenine wasps, is 
nearly impossible without abundant material. Yet it would require an unusual effort to collect just a few "wild" nests of Ancistrocerus antilope, for example, even though the wasp abounds in the region, and extraordinary luck were any such nests to prove recently closed by the mother and to contain unhatched eggs. In fourteen years I have found but one natural nest of this wasp, and that was constructed in a vacated nest of Sceliphron and contained but two cells. Any who wish to check or extend my results, or to investigate other aspects of the immature stages of Ancistrocerus and its burrow-nesting allies, will find the use of "trap nests" very helpful (Cooper I953).

Although hitherto not known to occur in Hymenoptera (van Emden 1925, 1946), it is likely that ruptor ovi will be found to be widespread among the eumenine wasps at the very least. A second species of eumenine nesting in my traps, which regrettably I did not rear, also has ruptor ovi developed in the very same sites on the thorax and on the first three abdominal segments as those of $A n$ cistrocerus antilope; they have, however, a distinctly different patern of grouping and fusion of their cuticular spines. Ruptor ovi may thus prove serviceable in generic or specific identification of first instar larvae of eumenine wasps. It is also probable that ruptor ovi will be found elsewhere among the aculeates, even though the few descriptions and figures which I have found of wasp larvae at instar-I fail to suggest their presence; for example, the cases of Sapyga (Soika I832), Crabro (Hachfeld I948), Omalus, Chrysis, Astata, Stizus, Sceliphron, Philanthus, and Tachysphex (Grandi 196r), and so on. By analogy with the polyphagous Coleoptera, however, where a ditferent thoraco-abdominal distribution of egg bursters is common even though species of many genera and perhaps families are without them (van Emden I946), it is quite possible that closely allied aculeates do differ widely in their means of hatching, and ruptor ovi are not universal among them.

Although five appears to be the primitive, most frequent, and upper number of larval instars found in Hymenoptera (see Bischoff I927, DeBach and Schlinger I964), it might be argued that, as in Tineola and some dermestid beetles, the number of moults may in principle be indeterminate. Certainly excessive feeding does not lead to a sixth instar larva. When a fifth instar larva is provided continuously with food, it may eat prodigiously (Cooper 1957), but there comes a point at which it ceases feeding. This is not, however, followed by a moult that gives rise to an additional larval instar. The excessively corpulent larva simply follows the normal routine that marks the close of the fifth instar: cell cleaning, cocooning, passage 
of the meconium (which is voluminous), then entrance either to the so-called pronymphal stage and succeeding sixth moult, or to diapause, remaining an eonymph. Nor have I been able to influence the numbers of moults that surviving larvae undergo by attempting to starve them from the second instar on. Five larval moults, therefore, appear to be the normal number. On enquiry, Prof. O. W. Richards informs me that it has been clearly shown that $V$ espa orientalis Linn. also has five larval instars. It is thus possible that du Buysson (I903) erred in his determination of the larval moults of Vespa, and that possession of five larval instars is both primitive and quite general among Vespidae just as it seems to be for many other aculeates, both bee (Bertholf 1925) and wasp (DeBach and Schlinger I964), as well as for the order Hymenoptera as a whole. Because no moult separates the fifth instar from the clearly defined prepupa, Morris's ( 1937) suggestion that an instar has been lost in development of the Ichneumonidae (as compared with the "lower phytophagous Hymenoptera") would seem to apply with equal force to eumenids and perhaps all other aculeates.

The prepupa, or fully-fed, quiescent fifth instar larva, or eonymph, tends regularly to enter diapause in the case of our northeastern Symmorphus cristatus, there being but one brood each year. Yet exceptions occur, for in one trap nest the sibs in all cells save one entered diapause as usual; the remaining individual transformed to a pupa which eclosed as a normal adult early that same fall. In principle then, $S$. cristatus is capable of being bivoltine. I have also had several prepupal Ancistrocerus antilope and Rygchium megaera remain flaccid and dormant as eonymphal prepupae through two years, even though all of their sibs broke diapause more or less together and transformed to adults in the usual time. When placed out of doors in their third winter, these blocked prepupae transformed to normal adults in the following spring. They were at that time not less than three years old. Meade-Waldo (I9r3) has had similar experience with prolonged prepupal states (of 2-3 years) in Raphiglossa Alavo-ornata (P. Cam.) as has Williams ( I919) with Tiphia ashmeadi Crawf. Morris (1937) comments that in Sweden nearly two thirds of the overwintering, diapaused, prepupal ichneumon fly Exenterus abruptorius Thb. emerged in the spring of 1935, and the remainder again over-wintered to emerge in the spring of 1936 . Such instances indicate the possibility that recombinant genomes of these hymenopterans need not always be selectively tested or passed along within one generation, or even within immediately consecutive generations as may happen with regularly bivoltine species.

There have been many observers who have commented on mason 
wasps' use of water in mixing mortar. Some have suggested that the masoning wasp may also use a special fluid from its mouth (e.g., Ferton I92I, Hicks I93I). This could be a secretion of its own ("saliva"), or possibly substances in solution or suspension which are derived from plants or prey and which provide an adhesive agent. Perhaps this is so, and excessively hard, masoned nests may indeed owe their refractoriness in important part to organic constituents provided by the wasp, as Ferton's (1921) comments seem to suggest. If that is the case, proventricular or other fluid used by adult mason wasps during emergence from their nests may in turn possess an added and complementary emollient, analogous to the cocoon-softener claimed for the saw-fly Trichiosoma tibiale which, so far as known, is unique within the Hymenoptera (see Hinton 1946).

\section{SumMary}

The larva of Ancistrocerus hatches from the egg by means of thoraco-abdominal ruptor ovi, or egg bursters. Development is hypermetamorphic, with a total of five larval instars. Presumably one moult (and one instar) has been lost in development, namely that moult which sets the strictly prepupal instar apart in phytophagous Hymenoptera. Exit from the masoned nest by emerging eumenine and masarine wasps involves resoftening the hardened mortar with drops of fluid (from the proventriculus in the case of $A$. antilope).

\section{References Cited}

BeRTHOLF, L. M.

1925. The moults of the honeybee. Jour. Econ. Ent. 18:380-384.

BischOFF, $\mathrm{H}$.

1927. Biologie der Hymenopteren. Biologische Studienbücher 5, viii + 598 pp., Springer, Berlin.

BuYsson, R. DU

1903. Monographie des guêpes ou Vespa. Ann. Soc. Ent. France. 72: 260-288.

COOPER, K. W.

1953. Biology of eumenine wasps. I. The ecology, predation and competition of Ancistrocerus antilope (Panzer). Trans. Amer. Ent. Soc. 79: 13-35.

1957. Biology of eumenine wasps. V. Digital communication in wasps. Jour. Exp. Zool. 134: 469-514.

Davidson, A.

1913. Masaria vespoides. Bull. So. Calif. Acad. Sci. 12: 17-18.

DeBach, P. and E. I. Schlinger (editors)

1964. Biological control of insect pests and weeds. xxiv +844 pp. Reinhold, New York.

EMDEN, F. VAN

1925. Zur Kenntnis der Eizähne der Arthropoden, insbesondere der Coleopteren. Zeits. wiss. Zoöl. 126: 622-654. 
1946. Egg-bursters in some more families of polyphagous beetles and some general remarks on egg-bursters. Proc. Roy. Ent. Soc. London. (A) $21: 89-97$.

FERTON, C.

1921. Notes détachées sur l'instincte des Hyménoptères mellifères et Grandi, G. ravisseurs. $9^{c}$ Sér. Ann. Soc. Ent. France. 89: 329-375.

1961. Studi di un entomologo sugli imenotteri superiori. Boll. Ist. Ent. Univ. Bologna. 25: xv $+659+1 \mathrm{pp}$.

HACHFELD, G.

1948. Ökologische und morphologische Beobachtungen an mitteleuropäischen Crabronen (Hym. Sphec.). I. Zool. Jahrb. (Abt. Syst.,

Hicks, C. H. Ökol., Geogr. Tiere). 77 : 49-80.

1927. Pseudomasaris vespoides (Cresson), a pollen provisioning wasp. Canad. Ent. 59: 75-79.

1929. Pseudomasaris edwardsii Cresson, another pollen-provisioning wasp, with further notes on P. vespoides (Cress.). Canad. Ent. 61: 121-125.

1931. Notes on pollen-user wasp, Pseudomasaris edwardsii Cresson, Bull. So. Calif. Acad. Sci. $30: 23-29$.

Hinton, H. E.

1946. A new classification of insect pupae. Proc. Zool. Soc. London. 116: 282-328.

HUNGERFORD, H. B.

1937. Pseudomasaris occidentalis (Cresson) in Kansas (HymenopteraVespidae). Jour. Kansas Ent. Soc. 10: 133-134.

IWATA, $\mathrm{K}$.

1925. The comparative anatomy of the ovary in Hymenoptera. Part I. Aculeata. Mushi. 29: 17-34.

Meade-Waldo, G.

1913. New species of Diploptera in the collection of the British Museum. Ann. Mag. Nat. Hist. (8) 11: 44-54.

MORRIS, K. R. S.

1937. The prepupal stage in Ichneumonidae, illustrated by the lifehistory of Exenterus abruptorius, Thb. Bull. Ent. Res. 28 : 525-534.

Nielsen, E. T.

1932. Sur les habitudes des Hyménoptères aculéates solitaires. II. Vespidae, Chrysididae, Sapygidae \& Mutillidae. Ent. Medd. 18: 84-174.

SoIkA, A. G.

1932. Études sur les larves des Hyménoptères (1). Ann. Soc. Ent. France. 101: 127-130.

TAYLOR, L. H.

1922. Notes on the biology of certain wasps of the genus Ancistrocerus (Eumenidae). Psyche 29: 48-65.

WHEELER, W. M.

1889. The embryology of Blatta germanica and Doryphora decemlineata. Jour. Morph. 3: 291-386.

Williams, F. $\mathbf{X}$.

1919. Philippine wasp studies. Part 2. Descriptions of new species and life history studies. Bull. Hawaijan Sugar Plant. Assoc., Ent. Series, no. 14: 19-186. 

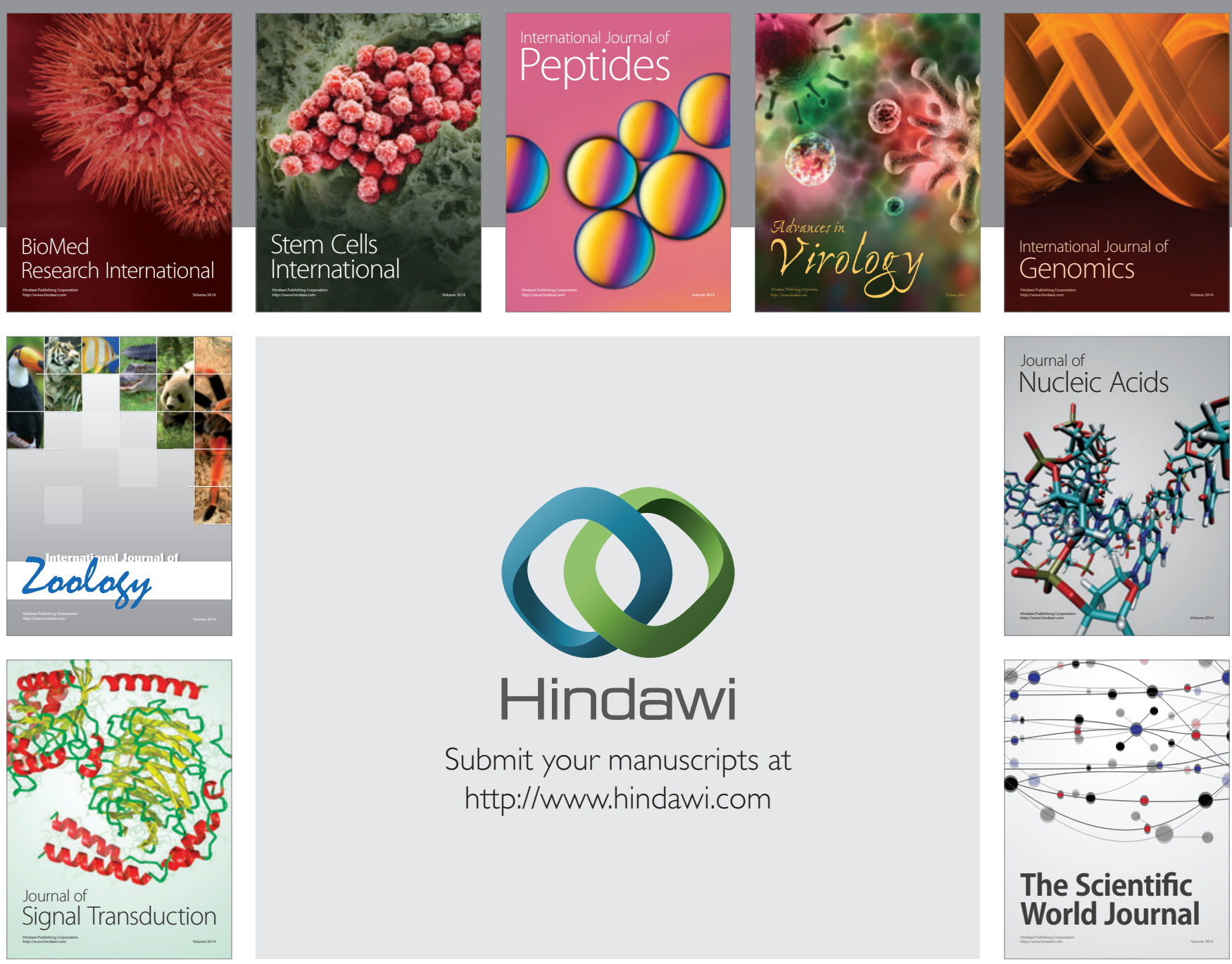

Submit your manuscripts at

http://www.hindawi.com
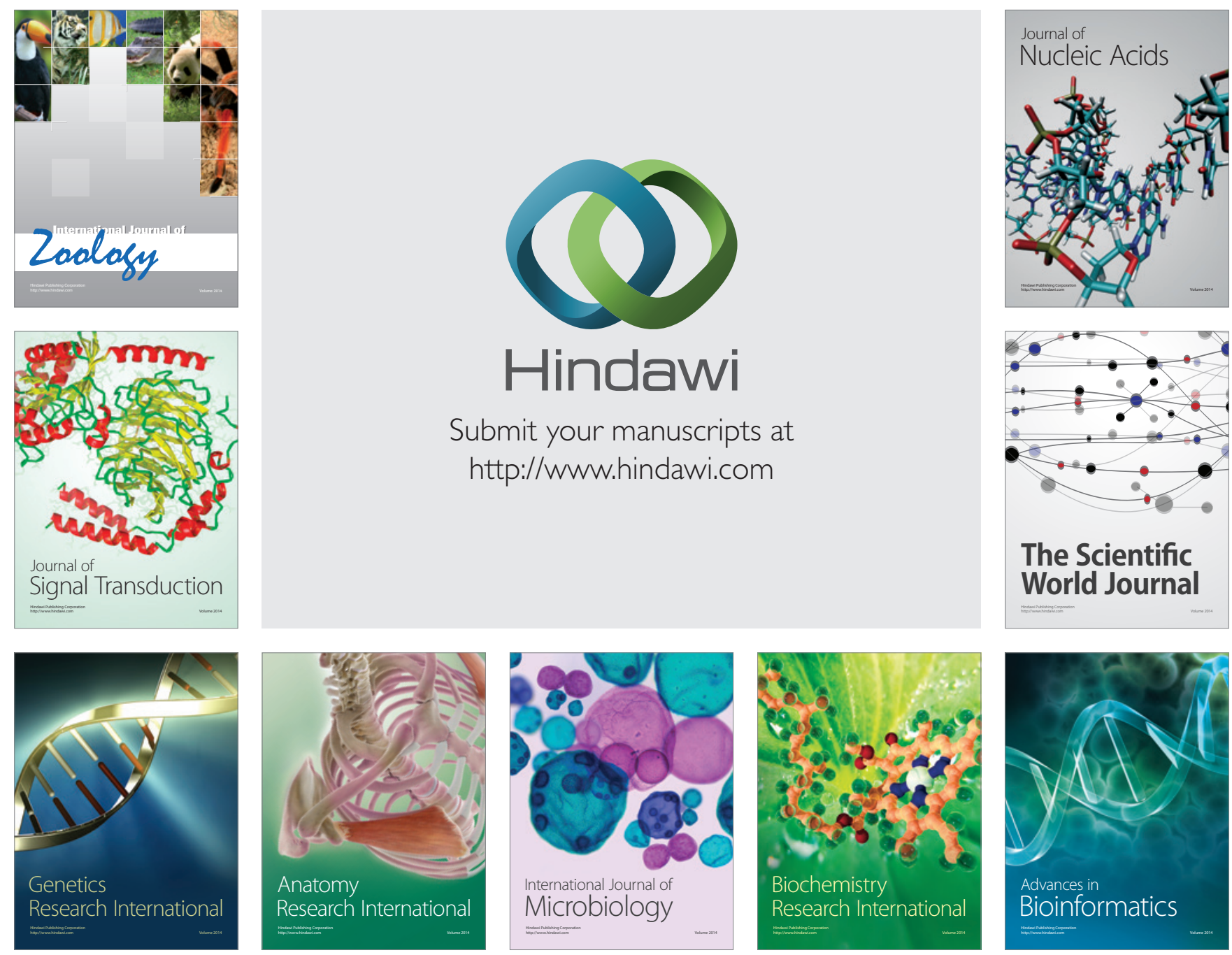

The Scientific World Journal
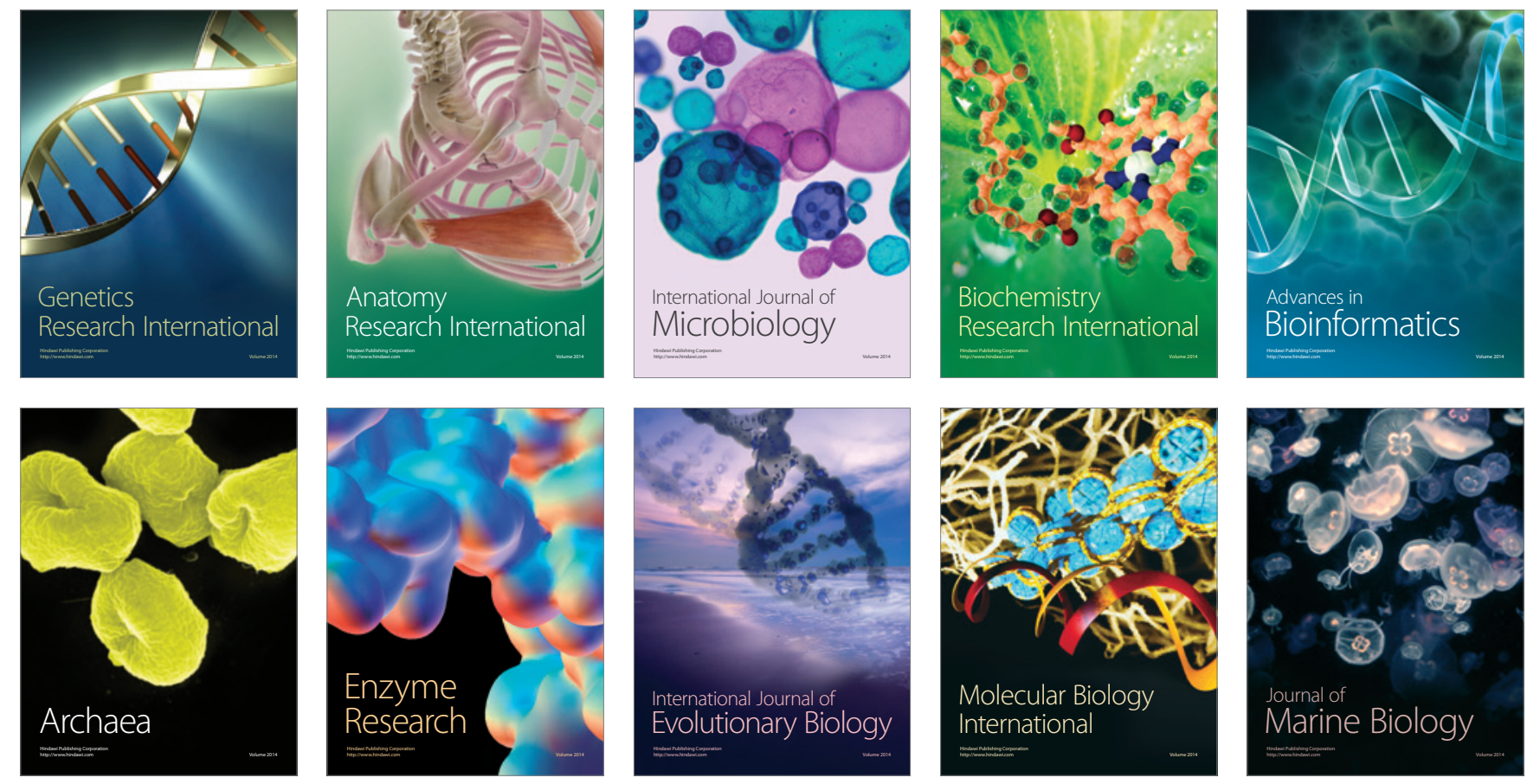